\title{
The Relationships of Reading Comprehension Ability with the Ability to Understand The Questions of Mathematical Word Problems
}

\author{
Prof. Dr. Auzar, M.S. \\ Faculty of Teacher Training and Education \\ Universitas Riau
}

Doi: $10.2478 / \mathrm{mjss}-2018-0084$

\begin{abstract}
This research described the relationships of reading comprehension ability with the ability to understand the questions of mathematical word problems. Some 40 students of Elementary School 155 Tampan Pekanbaru were taken as the sample of the research. The data were gathered using a reading comprehension test and a test of understanding questions of mathematical word problems. The results showed that the average score of reading comprehension is 5.83 and the average score of understanding the questions of mathematical word problems is 4.13. The relationships between the two variables were $r=0.31$. This score indicates that there are no strong or significant are relationships between reading comprehension with the ability to understand questions of mathematical word problems. So, the hypothesis stating that when a reading ability is high, the ability to understand questions of mathematical word problems will also be high is rejected.
\end{abstract}

Keywords: reading, comprehension, understanding, relationships, word problems

\section{Introduction}

Language is needed to communicate a concept to other people (Bruner, 1990). Language is also required to understand the questions of the mathematical word problems or word problems. Mathematics language that uses symbols is intended to ease someone to make an analysis so that $\mathrm{s} /$ he can solve his/her life problems related to the use of Mathematics. One will be able to solve problems in Mathematics when supported by the understanding of language with familiar situations and by using symbols which were already known before hand. Therefore, the language being used in books should use simple language based on the students' language development level. In other words, mathematical word problems should be realistic in terms of language, symbols, and situation.

The understanding of language in the form of questions in sentences is related to the ability to read them. Reading is an integrated activity that includes such activities as knowing letters and words, relating those letters and words with sounds and meaning (Akhadiah et al. 1991).

Reading is an effective tool for learning as it provides students with power to make an accurate decision in developing the learning process and thought. A reader can understand and evaluate the text he is reading by activating the schematic procedure and schematic content he has in himself. The reading process is a cognitive process which is experienced individually. This process is vital to help develop one's reading power (Nambiar, 2005).

Abushihab (2008) views that reading is an interactive process that involves such aspects as psychology, linguistics, and sociology. By interactive process, reading means that the reader creates meaning through a set of a mental process whereby there is a continuous interaction between the reader and the text. In the reading process, students are encouraged to work there 
thinking which is called creative reading where they make an evaluation, draw inferences to arrive at a conclusion. When readers are faced with a text, they break it into grammatical elements and simultaneously activate concepts and relations in the sense that when one item of knowledge is activated other things closely related to it in a mental process will also be active.

Reading is an activity or cognitive process that seeks to find a variety of information in writing or text. Reading can also be regarded as the activity of the complex by moving or using most of the action is fragmentary, includes the reader should use the definition of delusion, observing, and remembering are connected with the scheme reader. Furthermore, reading is the activity or process of applying various skills to cultivate reading text to understand the content of the readings. Therefore, reading can be said as the activity of obtaining information or message delivered by the author in writing. In this case, reading means understanding the reading text, both in literal, interpretive, critical, and creative (Dalman, 2013)

Reading, in reality, is a complex involving a lot of things, not just recite the words, but also involves visual, think, psycholinguistics and metacognitive. As the visual process, reading is the process of translating written symbols (letters) into spoken words. As a process of thinking, reading activities include word recognition, comprehension literal, interpretation, critical reading, and creative understanding. Word recognition can be reading words using dictionaries (Crawley and Mountain, 1995).

When a reader is reading a text, he participates in a conversation with the text writer through his cognitive activity. The reader, on the other hand, needs to apply appropriate reading strategies that are vital in order to comprehend a text successfully (Zare, 2012; May, 2001; Walker, 2000). Alexander \& Jetton (2000) argue that the reader when reading reveals cognitive effort through certain procedural strategy, aims, have attempted, intentional, important, and facilitative; in other words, the reader should use intentional and deliberate strategy to adjust and improve learning and understanding.

Questions in the form of sentences are certain items in Mathematics presented in the form of language in sentences of daily life (Hudoyo, 1998). Such questions, in general, contain mathematical concept such as multiplication, addition, reduction, and division. Therefore, in order to complete questions in sentences, students need to converse them into figures. It means students are dealing with two processes, i.e. the process of understanding series of sentences and the process of converting the sentences into figures.

The conversion of series of sentences into figures requires a skill of understanding texts which is more known as reading for comprehension. The conversion will run smoothly when the students understand the text they are reading well and understand the concept of Mathematics such as multiplication, addition, reduction, and division. These two components are closely related to each other in order to understand and complete the word problems.

Students must understand the language of mathematics if they want to successfully learn mathematics (Moschkovich, 2012). The word problems is an important aspect of mathematics and the process of mathematical thinking. However, in daily work, students have difficulties solving word problems because to solve the word problems require skills. They are easy to do basic mathematical operations, such as addition, subtraction, multiplication, and division. The student skillfully identifies the unit of measurement, and perform calculation tasks with numbers and equations. However, when working on word problems, many students try hard to do it and always failed. In some cases, students attempt to solve word problems and be able to identify some of the elements of the problem, but can not complete all the necessary operations (Vula \& Kurshumlia, 2015).

The ability to understand the language of mathematical word problems is related to the ability to read for comprehension because both require the ability to comprehend a text. If the students are unable to comprehend the text, it means they will not be able to tell what the text is about; moreover, to complete the question items related to the text as described in the mathematical word problems. According to Pearson \& Hamm (2003), understanding word problems is same as understanding the text of the other types because both the text have the equation of elements, but arranged differently. "Understanding the paragraph is the same as problem-solving in mathematics because both of them consist of selecting the right elements in the situation and put them together in the right relationship, and also with the right amount, the balance or the influence or power of each". 
Hudoyo and Surawidjaja (1997) reveal that to complete mathematical word problems can be done by (1) reading and re-reading the question or the item, trying to understand word by word and sentence by sentence; (2) identifying what is known about the problem; (3) identifying what to do; (4) neglecting anything irrelevant with the problem; (5) adding no unnecessary things that make the problem different from the one being faced. The above points correspond to the idea of Soedjadi (2000) stating that in general, to complete mathematical questions can be through the following stages: (1) reading each question or each item carefully and trying to catch the meaning of every sentence; (2) separating and mentioning what is known the item, what is demanded and asked for the item, the mechanism to deal with the item; (3) creating mathematical models of the item; (4) completing the models in accordance with the rules of Mathematics so that answers can be obtained from the models; and (5) returning the answers to the original answers.

\section{Research Problems}

The ability to read for comprehension is important to be possessed by the first year students of elementary school (ES) because by having this ability students will find it easy to understand a text they are asked to read. When related to reading the language of the mathematical word problems, the ability to read for comprehension is also needed since the mathematical questions require the language that can be well-understood by the students. Therefore, this research attempted to study the relationships of reading comprehension ability with the ability to understand the questions of mathematical word problems.

The problems investigated are as follows:

1) How is the reading comprehension ability of the fifth year students of ES 155 Pekanbaru?

2) How is the ability to understand the language of mathematical word problems of the fifth year students of ES 155 Pekanbaru?

3) Is there a significant the relationships of reading comprehension ability with the ability to understand the questions of mathematical word problems of the fifth year students of ES 155 Pekanbaru?

\section{Methodology}

This research employed the correlation method with a test technique to collect the data. The sample of the research was all the fifth year students of ES 155 Pekanbaru totaling 40 students. The sample was tested twice. The first test was intended to measure the students' reading comprehension ability and their ability to understand the language of the mathematical word problems. For the latter, the students were not supposed to complete the questions but tried to understand the questions or understand the mathematical language. The students were required to understand the concept of the questions related to multiplication, addition, reduction and division.

\section{Result}

\subsection{Reading Comprehension Ability}

The test results showed that the average score of the students' reading comprehension ability was 5.83 as presented in the following table:

Table 1. The reading comprehension ability of the fifth year students of ES 155

\begin{tabular}{lllcll}
\hline $\mathbf{N}$ & Score & Frequency & Percentage (\%) & Average & Category \\
\hline 40 & 2 & 1 & 2.5 & 5.83 & Low \\
& 3 & 2 & 5.0 & & \\
& 4 & 3 & 7.5 & & \\
& 5 & 7 & 17.5 & & \\
& 6 & 13 & 32.5 & & \\
7 & 12 & 30.5 & & \\
& 7 & 2 & 5.0 & & \\
\hline
\end{tabular}


Table 1 shows that the lowest score is 2 with the frequency of $1(2.5 \%)$, score 3 with the frequency of $2(5.0 \%)$, score 4 with the frequency of $3(7.5 \%)$, score 5 with the frequency of $7(17.5 \%)$, score 6 with the frequency of $13(32.5 \%)$, score 7 with the frequency of $12(30.0 \%)$, and score 8 (the highest score) with the frequency of $2(5.0 \%)$. The average score is 5.83 which is categorized into low. It means that the reading comprehension ability of the fifth year students of ES 155 Pekanbaru is in a low category.

\subsection{The Ability to understand the questions of mathematical word problems}

Based on the test results of understanding the questions of mathematical word problems, the average score of 4.13 was obtained. The detailed description of the test results is presented in Table 2 below:

Table 2. The Ability to understand the questions of mathematical word problems

\begin{tabular}{cllcll}
$\mathbf{N}$ & Score & Frequency & Percentage (\%) & Average & Category \\
\hline 40 & 1 & 1 & 2.5 & 4.13 & Low \\
& 2 & 8 & 20.0 & & \\
3 & 8 & 20.0 & & \\
& 4 & 5 & 12.5 & & \\
5 & 9 & 22.5 & & \\
6 & 5 & 12.5 & & \\
7 & 3 & 7.5 & & \\
8 & 1 & 2.5 & & \\
& & & & & \\
&
\end{tabular}

Tabel 2 displays the ability of ES 155 students to understand the questions of mathematical word problems. The students' lowest score is 1 with the frequency of $1(2.5 \%)$, whereas the highest score is 8 with the frequency of $1(2.5 \%)$. Score 2 with the frequency of $8(20 \%)$, score 3 with the frequency of $8(20 \%)$, score 4 with the frequency of $5(12.5 \%)$, score 5 with the frequency of 9 $(22.5 \%)$, score 6 wth the frequency of $5(12.5 \%)$, score 7 with the frequency of $3(7.5 \%)$. The average score is 4.13 . It means that the ability to understand the language of mathematical word problems of ES 155 students is categorized into low.

\subsection{The relationships of reading comprehension ability with the ability to understand the questions} of mathematical word problems

Based on the correlation test between reading comprehension ability and the ability to understand the questions of mathematical word problems, it was found out that the $r$ value was 0.31 . The detailed description of the test results is given in the following table:

Table 3. The relationships of reading comprehension ability with the ability to read to understand the questions of mathematical word problems

\begin{tabular}{llclll}
\hline Tes type & N & Average & $\begin{array}{c}\text { Deviation } \\
\text { Standard }\end{array}$ & $\begin{array}{c}\text { Correlation } \\
(\mathbf{r}=)\end{array}$ & Signif. \\
\hline $\begin{array}{l}\text { Reading for Compre. } \\
\begin{array}{l}\text { Understanding } \\
\text { the language of }\end{array}\end{array}$ & 40 & 5.83 & 1.35661 & 0.31 & 0.850 \\
the question items & 40 & 4.13 & 1.75685 & 0.31 & \\
\hline
\end{tabular}

The above table presents the relationships of the reading comprehension ability of ES 155 students with their ability to read to understand the questions of the mathematical word problems. The table shows that the $r$ value is 0.31 . According to Riduwan (2005), such $r$ value means that the correlation between the two variables is categorized into low $(0.20-0.399)$. That is to say, the relationships between the two components are not significant $(0.850>0.05)$. Therefore, the hypothesis stating that when reading comprehension ability is high, the ability to read to understand 
the questions of the mathematical word problems will also be high is rejected which can be seen from the average score of the students' understanding of the questions of mathematical word problems which is only 4.13 compared to 5.83 for reading for comprehension.

\section{Discussion}

The finding of the research indicated that the average score of ES 155 students in reading comprehension was 5.83 . This score was higher than their average score in understanding the questions of mathematical word problems that was 4.13. These two scores had low correlation where the $r$ value was 0.31 . These two insignificant abilities occur because the Mathematics language has its own register which is different from the general language or ordinary language. Parveen, et al. (2013) states that reading comprehension is taught in schools and colleges, but students have comprehension difficulties as they lack reading fluency as a result of having no reading practice either at school or at home. In other words, they do not have a reading habit and reading interest which are partly caused by internal and external factors that affect their reading readiness, reading attitude and reading comprehension. The students have no knowledge about reading strategies or techniques by which they could fully comprehend the content of a text; consequently, they just try to memorize the alternatives for the answers in the exams. They still do not realize that reading is very important because it can be more understand information about higher education and the workplace. They must know that the mental model is a symbolic representation of the minds of people who are able to understand information in the form of pictures, gestures, analogies, concept maps, story webs, and others. In the academic field or in the classroom situation, teachers can enhance students ' ability in reading comprehension with the use of mental models, for example, guide the student to read so that students can develop reading readiness, have the attitude to read, understand and read fluently. It has been proved in experiments conducted in VV College of Engineering.Reading can be challenging, especially when the reading material is relatively new, technical, or complex. In addition, for some readers, understanding is always challenging. They can understand every word separately, but linking the words simultaneously be an idea-the idea of meaningful is often not the case as it should be. Readers like this can connect words, but can not develop adequate skills to understand the basic meaning, the deeper meaning of sentences, paragraphs, and entire text. Such an understanding refers to the ability to go beyond the words, to understand ideas and relationships between ideas presented in the text (McNamara, 2007).

Many children have not had experiences that make them "love" reading. For these children who are not as interested in reading, the need to take a time to help link their interests to reading is even more important (Blachowicz \& Ogle, 2008).

Many mistakes made by students when answering a mathematical word problems matter. Error solve math problems consist of errors the concept of, errors in the completion of the steps, and/or errors in count algebra (Lestari, et al, 2010). According to White (2005), the error occurs when the student can determine the operations that must be performed, but can not perform the procedure of such operations.

The language of Mathematics is not a free language for its own vocabulary, series of sentences and discourse can bring about problems for the students who learn it (Barton \& NevilleBarton, 2003). Kline in Suriasumantri (1995), views that Mathematics language is a very symbolic language.

Clapham (1996) conducted a study that provided an initial understanding of how language influenced mathematical understanding of English speakers as their second language. This study showed that the second language learners at university level had very low achievement in Mathematics beyond what was expected that was about $10 \%$. It means that technical language, in particular, is very important as it is not the language used in everyday life.

Barton \& Neville-Barton (2003) reveal that Mathematics language is not a 'free language'; its special vocabulary, syntax, and discourse become a challenge for the second language learners. The second language learners are usually very successful in answering graphic questions, but they fail when being faced with symbolic and diagrammatic language. 
Sepeng P. and Sigola (2013) illustrates that students have difficulty in reading and understanding the problems with mathematical language. According to Prakitipong \& Nakamura (2006), the analysis of Newman Procedure, namely the method of analyzing the error of the sentence, indicating that students experiencing obstacles in the completion of the word problems because they are not fluent and don't understand the concepts in the readings and do not understand the meaning of a problem. Hakverdi, et al (2011) states that students must have a semantic knowledge to help students understand the purpose of interpreting the issues and problems correctly. Therefore, to reduce the level of student difficulties in understanding the intent matter, the student must have knowledge of semantics that can interpret the intention of matter and analyze all the problems.

All of the students consider that studying and understanding the language of mathematics is very challenging. For students, learning vocabulary is difficult and hard to remember because of the words of mathematics is different with English words that they use everyday. According to Rubenstein and Thomson (2002), there are some reasons that cause the students difficult to understand the language of mathematics. The reason is

1. English and mathematics have the same words, but different meaning in different context. Example: Right angle versus right answer

2. A few words found only in mathematics, but not found in English day-to-day. Example: isosceles, quotient

3. Some math word contains the meaning of polysemy or more than one meaning. Example: A circle is round versus to round a number to the tenths place

4. Some of the math word is a homonym for the English words. Example: sum versus some, pi versus pie

5. Some of the math concepts experienced verbalizing more than one way. Example: Onequarter versus one-fourth

In addition, both formal and informal, students transfer math terminology as they acquire and retain knowledge. Learning of mathematics requires a transformation from a weak ability to understand mathematics to the ability to master the language of mathematics." (Herbel-Eisenmann, 2002).

\section{Conclusions}

On the basis of the data analysis and discussion, some conclusions can be drawn as in the following:

1) The ability of ES 155 students in reading comprehension was categorized into the low that was 5.83 .

2) The ability of ES 155 students in understanding the language of mathematical word problems was categorized into low that was 4.13 and

3) There was not a significant the relationships of reading comprehension ability with the ability to understand the questions of mathematical word problems

\section{Acknowledgement}

This research was sponsored by Institute for Research and Community Service of Universitas Riau.

\section{References}

Abushihab, I. (2008). Taking Reading Beyond Comprehension Level by Developing Critical Thinking in Classroom. Ekev Academic Review; Fall 2008, Vol. 12 Issue 37, (p373).

Akhadiah, M.K., Sabarti, Maidar G.A, \& Sakura H.R. (1991). Bahasa Indonesia I. Jakarta: Departemen Pendidikan dan Kebudayaan.

Alexander, P.A., \& Jetton, T.L. (2000). Learning from text: A multidimensional and developmental perspective. In M.L. Kamil, P.B. Mosenthal, P.D. Pearson, \& R. Barr (Eds.), Handbook of reading research (Vol. 3, 285-310). Mahwah, NJ: Erlbaum.

Blachowicz, C. \& Ogle, D. (2008). Reading Comprehension. Strategies for Independent Learner. New York: The 
Guilford Press.

Barton, B., \& Neville-Barton, P. (2003). Language issues in undergraduate mathematics: a report of two studies. New Zealand Journal of Mathematics, 32, 19-28. Supplementary Issue.

Bruner, J. (1990). Acts of Meaning. Cambridge: Havard University Press.

Clapham, C. (1996). The Development of IELTS: A study of the effect of background knowledge on reading comprehension. The Cambridge: Cambridge University Press.

Crawley, S.J. \& Mountain, L. (1995). Strategies for Guiding Content Reading. Boston: Allyn and Bacon.

Dalman, D. (2013). Keterampilan Membaca, Jakarta: PT Raja Grafindo Persada.

Haghverdi, M., Semnani, A.S, \& Seifi, M. (2011). "The Examining Two Approaches for Facilitating The Process of Arithmetic Word Problems Solving". International Journal for Studies in Mathematics Education 4(1): $135-147$.

Herbel-Eisenmann, B. (2002). Using student contributions and multiple representations to develop mathematical language. Mathematics Teaching in the Middle School 8(2), 100-105.

Hudoyo, H. (1990). Strategi Belajar Mengajar Matematika. Malang: IKIP Malang.

Hudoyo, H. \& Surawijaya, A. (1997). Matematika. Bagian P3GSD Ditjen-Dikti Depdikbud, Jakarta.

Lestari, N.I., Anton N., \& Wardani R. (2010). "Analisis Kemampuan Siswa SD dalam Menerjemahkan Soal Cerita ke dalam Model Matematika dan Penyelesaiannya". Jurnal Matematika , Aplikasi dan Pembelajarannya. 9(1): 22-34.

McNamara, D.S. (Edt.) (2007). Reading Comprehension Strategies. Theories, Interventions, and Technologies. New York: Lawrence Erlbaum Associates. Taylor \& Francis Group.

May, F. B. (2001). Unraveling the seven myths of reading. US: Allyn and Bacon.

Moschkovich, J. (2012). Mathematics, the Common Core, and language: Recommendations for mathematics instruction for ELs aligned with the Common Core. Retrieved from http://ell.stanford.edu/sites/default/files/pdf/academic-papers/02JMoschkovich\%20Math\%20FINAL_bound\%20with\%20appendix.pdf. (January 23, 2017).

Nambiar, R. (2005). Language learning and language use strategies for academic literacy: Towards a theoretical and pedagogical model of language learning. Tesis Ph.D. Universiti Kebangsaan Malaysia, Bangi.

Parveen, J., Jaya \& Rajesh, V. (2013). "Mental Modelling in Guided Reading \& Paired Reading -- A Comparative Study". Language in India; Mar 2013, Vol. 13, Issue 3, p75

Pearson, P. D., \& Hamm, D. (2003). Reading Comprehension Assessment: One VERY Resilient Phenomenon. Paper presented at 2003 IRA Convention, Orlando, FL. Available online: http://www.ciera.org/library/presos/2003/index.html. (January 23, 2017).

Prakitipong, N. \& Nakamura, S. (2006). "Analysis of Mathematics Performance of Grade Five Students in Thailand Using Newman Procedure". Journal of International Cooperation in Education 9(1): 111-122.

Riduwan, R. (2005). Belajar Mudah Penelitian. Bandung: Alfabeta.

Rubenstein, R. N., \& Thompson, D. R. (2002). Understanding and Supporting Children's Mathematical Vocabulary Development. Teaching ChildrenMathematics 9(2), 107-112.

Sepeng, P., \& Sigola, S. (2013). "Making Sense of Errors Made by Learners in Mathematical Word Problem Solving". Mediterranean Journal of Social Sciences 4(13): 325-333.

Soedjadi, R. (2000). Nuansa Kurikulum Sekolah. Proceeding Konferensi Nasional X Matematika ITB, 17-20 Juli 2000.

Suriasumantri, J.S. (1995). Ilmu Dalam Perspektif Sebuah Kumpulan Karangan Tentang Hakekat IImu. Jakarta: Yayasan Obor Indonesia.

Vula, E. \& Kurshumlia, R. (2015). Mathematics Word Problem Solving Through Collaborative Action Research. Journal of Teacher Action Research. Volume 2. Issue1, (p. 34-46).

Walker, J. B. (2000). The diagnostic teaching of reading: Techniques for instruction and assessment (4th ed.). $\mathrm{OH}$ : Merril.

White, A.L. (2005). "Active Mathematics in Classrooms: Finding Out Why Children Make Mistakes - and Then Doing Something to Help Them". Square One 15(4): 15-19.

Zare, P. (2012). Language Learning Strategies Among EFL/ESL Learners: A Review of Literature. International Journal of Humanities and Social Science. 2(5): 162-169. 